\title{
Research
}

\section{Birds and the City: Urban Biodiversity, Land Use, and Socioeconomics}

\author{
$\underline{\text { Michael W. Strohbach }}^{1}, \underline{\text { Dagmar Haase }}^{1}$, and Nadja Kabisch $^{1}$
}

\begin{abstract}
We examined bird diversity in relation to land use and socioeconomic indicators in Leipzig, Germany. We used neighborhood diversity (ND) and bivariate correlation to show that the potential to experience biodiversity in a city is associated with population density, household income, unemployment, and urban green space. People living in urban districts with high socioeconomic status experience the highest species richness around their homes, whereas lower social status increases the chance of living in species-poor neighborhoods. High-status districts are located along forests, parks, and rivers that have a high quantity and quality of green space. However, green space in general does not guarantee high bird diversity. We conclude that bird diversity mirrors land use and socioeconomic patterns within the compact European city of Leipzig. Therefore, urban planning should focus on decreasing these patterns and protecting the remaining species-rich green spaces.
\end{abstract}

Key Words: biodiversity; human-environment interaction; neighborhood diversity; urban ecology

\section{INTRODUCTION}

Urban areas cover only $2.7 \%$ of the world surface (Center for International Earth Science Information Network 2004) and have been inhabited by the majority of the human population since 2008 (United Nations 2008). Likewise, they are the most domesticated landscapes on earth (Kareiva et al. 2007). The process of urbanization, as this domestication is usually called, generally leads to an environment that is favorable for humans. However, it can lead simultaneously to a host of environmental problems, including the loss of biodiversity (Grimm et al. 2008).

In examining the general role and extent of the impact that urbanization has on biodiversity, no general answer can be found. On a gradient of intensifying urbanization, i.e., the rural-to-urban gradient, the number of species of different taxonomic groups has been shown to peak at different levels. Breeding bird diversity has been found to decrease (Clergeau et al. 1998, 2006, Marzluff 2001) and to be lowest in urban centers (Blair 1999, Tratalos et al. 2007a). However, urban structures can provide a wide and heterogeneous range of habitats, depending on the intensity of urbanization (DeGraaf et al. 1991). They often encapsulate remnants of natural or semi-natural ecosystems that are lost elsewhere (Haase 2003, Crane and Kinzig 2005, Millard 2008). The effect on biodiversity also depends on where urbanization occurs. Savard et al. (2000) summarize the effect of urban land conversion on a given landscape as a function of its original composition: Urbanization is most likely to decrease biodiversity when the original landscape is diverse.

Urbanization is not a purely physical process that affects biodiversity. Many authors argue that socioeconomic patterns such as urban structure, population density, neighborhood image, or household income should be taken into account when studying urban ecosystems (Grove and Burch 1997, Dow 2000, Alberti et al. 2003). There is recent evidence that biodiversity mirrors socioeconomic patterns of income, age of development, and ethnicity within North American cities. Findings for Vancouver, Canada, demonstrate that the number of native bird species increases in relation to an increasing socioeconomic status that was measured by mean family income and number of people holding a university degree (Melles 2005). Similar patterns were found by Hope et al. (2003) and Kinzig et al. (2005), who identified substantial neighborhood differences in species richness 
according to the given income status in Phoenix, Arizona, USA. In both cities, neighborhoods with higher social status often have higher species diversity than neighborhoods with lower social status.

In addition to the abovementioned effects, urbanization also changes the way humans experience biodiversity. Turner et al. (2004) calculated the neighborhood diversity (ND) to study the species diversity at people's place of residence. ND indicates the number of species found within a certain radius of a home. Turner et al. (2004) compared the local ND and local human population to the citywide average ND for five cities on three continents. They found that 53 to $82 \%$ of the population lives in neighborhoods with belowaverage ND. They conclude that this might be the case for most urban human populations. This is important for two reasons. First, Miller (2005) and Dunn et al. (2006) argue that the loss of experiencing biodiversity on a daily basis causes an estrangement from nature, which might explain the lack of broadbased support for nature conservation in general. Second, urban green spaces provide important social, psychological (Chiesura 2004), and health (Ulrich 1984) benefits that are not only linked to their quantity, but also their quality (Fuller et al. 2007, Mitchell and Popham 2008). For example, Baines (2000) argues that bird life in urban parks enhances the recreational quality: People who go to parks during the day seek a "wildlife garden" atmosphere that differs from their work neighborhood. In summary, bird diversity is likely to vary across an urban region, and some of this variation is likely to be correlated with demographic and socioeconomic characteristics.

Given this experience, our purpose is to analyze whether this idea holds true for Leipzig, Germany. The city of Leipzig is a compact, central European city that is situated in the former Communist Bloc; the development of the city and its society has been very different compared to most North American cities. We therefore expect different relationships between bird diversity, land use, and socioeconomic patterns. Because we focus on the spatial and social aspects of potential urban human-nature interactions, we take the method developed by Turner et al. (2004) one step further by overlaying patterns of human populations living in neighborhoods of below-average ND with land use and socioeconomic data.

\section{METHODS}

\section{Study area}

Leipzig is located in eastern Germany $\left(51^{\circ} 20^{\prime} \mathrm{N}\right.$, $\left.12^{\circ} 22^{\prime} \mathrm{E}\right)$. The city reached its peak population of more than 700,000 inhabitants in the early 1930s, making it the country's fourth largest city. After WWII, the city entered its socialist period until 1990 and started to lose population. Faced with tremendous societal transition and the withdrawal of investment, the city lost approximately 100,000 inhabitants after the fall of the Berlin wall in 1989 , with 530,000 inhabitants in 1989 and 437,000 inhabitants in 1998.

Leipzig consists of a densely developed core with administrative and cultural facilities in the city center. The core is surrounded by a ring of tenement blocks from the Wilhelminian period (1890-1918; Fig. 1). A second residential ring is formed around Leipzig by terraced houses and villas, mainly built between 1900 and 1940, as well as huge socialistera prefabricated multistory housing estates in the western part of the city. Larger parts of the eastern and western city are covered by manufacturing and commercial land use. Many small and intensively used allotment garden plots are situated along railway tracks and around the city.

There are major differences in population density within the city area. The surrounding ring of terraced and single houses has a low population density of < 1000 inhabitants $/ \mathrm{km}^{2}$. The southern part and the inner western part of the Wilhelminian blockstructures, namely the municipal districts of Südvorstadt, Schleußig, Waldstraßenviertel, and Gohlis, belong to the districts with a population density close to the city's average of 4900 inhabitants $/ \mathrm{km}^{2}$ (Stadt Leipzig 1995). Inhabitants of higher income groups live in these districts. Districts with a higher population density include the simple or medium-quality Wilhelminian structures of the eastern part of Leipzig such as Volkmarsdorf and Neustadt-Neuschönefeld. These districts suffer from high vacancy accompanied by declining economic activity. In addition, the low quality of public spaces in some of these areas overlaps with social problems and increases the perception of a negative image (Haase et al. 2004). Districts with mainly socialist-era prefabricated multistory housing estates such as Grünau in the outer west had a population density of up to 18,000 inhabitants $/ \mathrm{km}^{2}$ in 1993 . They also suffer from a 
Fig. 1. Land-use classification of the study area of Leipzig, Germany, based on a map published in Haase and Nuissl (2007).

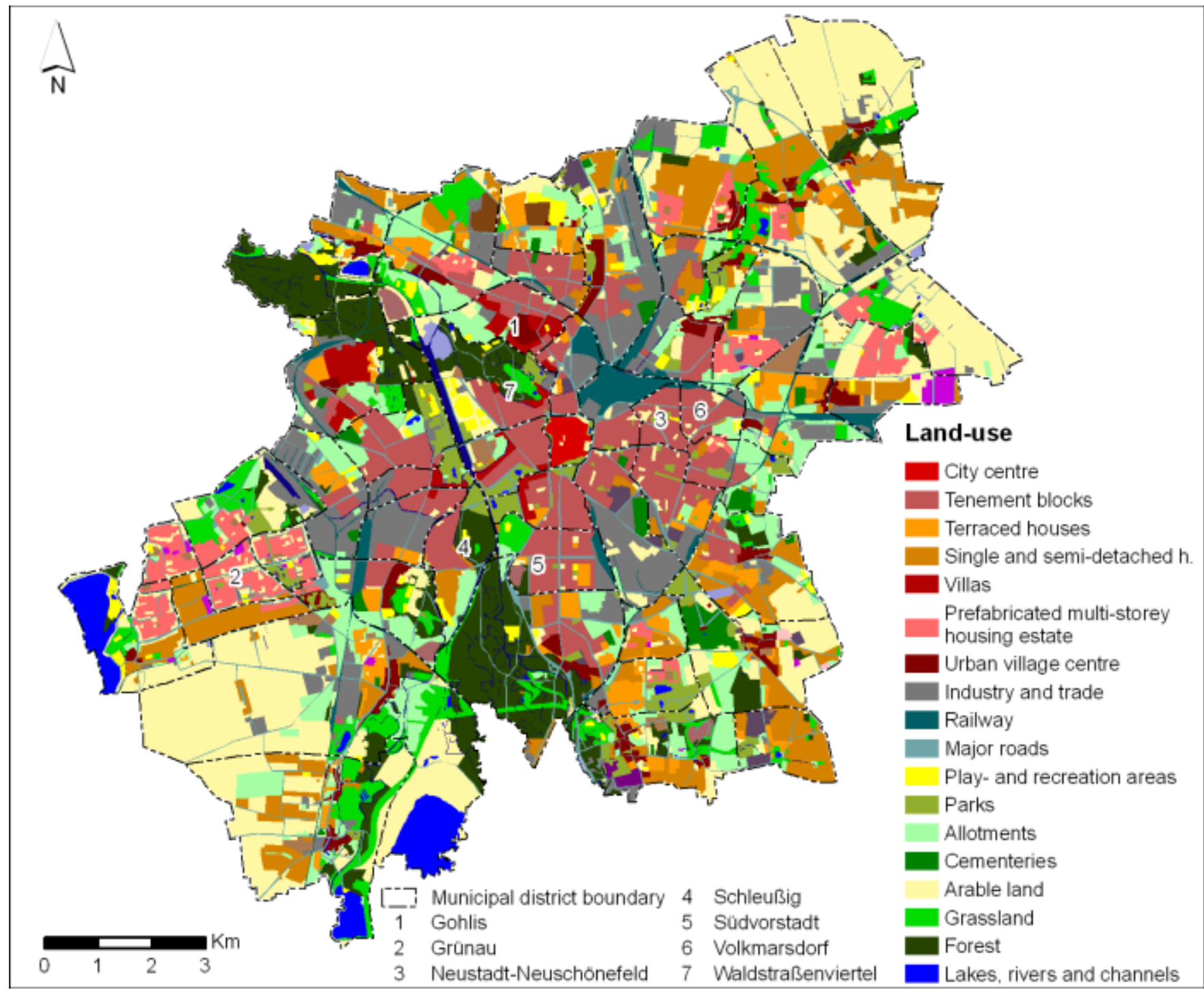

negative image because of the low housing quality and the perception that the inhabitants of such highdensity districts often belong to lower income and socially deprived groups (Kabisch et al. 2005). These municipal districts are indicated in Fig. 1.

Despite being compact, Leipzig contains a large quantity of green spaces. There are several large parks. The floodplains of the rivers Weiße Elster and Pleiße are covered by old riparian forests belonging to the association Querco-Ulmetum minoris Issler 1924 (Müller 1995) and meadows that make up approximately 6.3 and $4.1 \%$, respectively, of the city. Leipzig holds one of the largest and most diverse urban floodplains of Europe (Haase 2003). The floodplain separates the city into western and eastern parts. The soils in the floodplains are mostly loamy Fluvisols, but the major part of the city is covered by Pleistocene sediment-based Luvisols. 
In total, 109 breeding bird species were found within the city borders of Leipzig. This diversity is significant; the number of bird species in the entire Federal State of Saxony is 180 (Stefens et al. 1998) and in Germany is 314 (Völkl et al. 2004). Turdus merula (blackbird), Parus major (great tit) and Passer domesticus (house sparrow) have the largest ranges, occupying 93,84 , and $83 \%$ of the city, respectively. Diverse areas with rare species such as Dendrocopos medius (middle spotted woodpecker) are located along the floodplain, indicating the ecological value of the meadow forests. Only a few species are found in the densely built-up areas and intensively used rural agricultural surroundings. Only a few species are non-native, but those can be considered naturalized, e.g., Streptopelia decaocto (Eurasian collared dove).

\section{Indicators}

We used three sets of indicators: breeding bird diversity, land use, and socioeconomic indicators. We used breeding birds because they are a very wellstudied taxonomic group, providing good data availability. Furthermore, urban bird communities can be independent of bird communities in the rural surroundings at local and regional scales (Clergeau et al. 2001) and have been used to evaluate the ecological quality of urban green space (Sandtröm et al. 2006). Most importantly, birds are probably the most visible and audible taxonomic group for humans in cities. Land use is an indicator that contains information on both habitat quality and residential quality. For socioeconomic indicators, we used variables similar to Hope et al. (2003), Turner et al. (2004), Kinzig et al. (2005), and Melles (2005); we used population density and total number of companies, representing economic density, as indicators of land-use intensity. We used income level and unemployment as indicators of socioeconomic status. Finally, average household size and mean age were used to identify social segregation.

\section{Data}

The breeding bird survey of the region of Leipzig was carried out between 1991 and 1993 on a $500 \times$ $500 \mathrm{~m}$ sampling raster. In each year, the raster cells were surveyed by volunteer ornithologists at least five times between February and July. Only breeding species were mapped. If a species was found breeding in at least one of the three years, it was marked as present in the respective raster cell of the species atlas (STUFA 1995). The map of Leipzig's land-use structure was compiled by Haase and Nuissl (2007) for 1997 (Fig. 1), which is considered close enough to the survey period of the breeding birds. The information about socioeconomic patterns at the municipal district level $(n=49)$ was mainly taken from local census data. Data for population density, average household size, mean age, and number of companies per square-kilometer were available for 1994. Data for residential vacancy are from 1995, and those for unemployment rate are from 1996 (Stadt Leipzig 1995, 1997). For the income indicator, there was no information from 1994, 1995, or 1996; data were thus taken from the closest available year: 2003 (Stadt Leipzig 2004). We used the share of households with income $<1000 €$ and the share of households with income $>3000 €$, which were the most detailed indicators available. Although absolute levels of income have changed, the relative spatial differences are expected to be quite stable. See Tables 1 and 2 for lists of all variables used.

\section{Analysis}

The spatial data analysis was carried out using ArcGIS version 9.2, with the extensions Spatial Analyst 9.2, ET GeoWizards 9.6.1, and Patch Analyst 0.9.4. The statistical software R 2.7.1 was used for statistical analysis and visualization.

\section{Spatial Analysis}

In a first step, each bird survey raster cell with its centroid within the city area was selected and assigned to the municipal district that covered the majority of its area. The angular appearance of the districts is a result of that assignment (Figs. 2 and 3 ). In a second step, the raster of the breeding bird survey was intersected with the urban land-use map of Leipzig. We then calculated the relative cover of the single land-use classes for each raster cell and for each municipal district. Knowing the housing area and population of the municipal districts, we interpolated the human population of each raster cell using the housing area as a proxy.

We calculated the neighborhood diversity (ND) as a measure of how much bird diversity residents could experience on a daily basis within a certain 
Table 1. Spearman rank correlation between land use and the percentage of human population in neighborhoods with below-average neighborhood bird diversity at the municipal district level.

\begin{tabular}{lc}
\hline \hline Land use & Correlation (rho) \\
\hline Urban village center & -0.16 \\
Terraced houses & -0.16 \\
Prefabricated multistory housing estate & $0.24^{\circ}$ \\
Single and semi-detached houses & -0.02 \\
Tenement blocks & 0.20 \\
Villas & $-0.25^{\circ}$ \\
City center & 0.23 \\
Industry and trade & 0.08 \\
Railway & $0.35^{*}$ \\
Major roads & 0.13 \\
Sports and recreation areas & -0.07 \\
Parks & -0.14 \\
Allotments & -0.09 \\
Cemeteries & 0.15 \\
Arable land & -0.03 \\
Grassland & $-0.42^{* *}$ \\
Forest & $-0.65^{* * *}$ \\
Rivers and channels & $-0.66^{* * *}$ \\
Lakes & $-0.51^{* * *}$ \\
\hline
\end{tabular}

${ }^{\circ} \mathrm{p}<0.1, * \mathrm{p}<0.05, * * \mathrm{p}<0.01, * * * \mathrm{p}<0.001$.

radius around their home. ND indicates the number of species found within a survey cell and its respective neighbors (nine cells in total), which translates to a radius of 500-1000 m. ND represents the number of species found within that radius for a home within a survey raster cell. This accounts for government recommendations on the availability of natural green space in the proximity of homes in Germany (500 m; Hutter et al. 2004) and England
(300 m; Handley et al. 2003). There are no federal recommendations in the United States, but some communities have their own guidelines. Comparing the guidelines of several cities, Harnik and Simms (2004) found that the maximum allowable distance from a park was $890 \mathrm{~m}$ on average.

To visualize the relationship between population density and species diversity, we used the two 
Table 2. Spearman rank correlation between socioeconomic indicators and the percentage of human population in neighborhoods with below-average neighborhood bird diversity at the municipal district level.

\begin{tabular}{lc}
\hline \hline Socioeconomic parameter & Correlation (rho) \\
\hline Population density (inhabitants $\left./ \mathrm{km}^{2}, 1994\right)$ & $0.44^{* *}$ \\
Average household size (1994) & -0.03 \\
Mean age (1994) & -0.02 \\
Companies (number $\left./ \mathrm{km}^{2}, 1994\right)$ & $0.47 * *$ \\
Residential vacancy $(1995)$ & 0 \\
Unemployment $(\%$ of employable population, 1996) & $0.25^{*}$ \\
Share of households with income $<1000 €(2003)$ & $0.36^{*}$ \\
Share of population with income $>3000 €(2003)$ & $-0.31^{*}$ \\
\hline${ }^{\circ} \mathrm{p}<0.1, * \mathrm{p}<0.05, * * \mathrm{p}<0.01, * * * \mathrm{p}<0.001$. &
\end{tabular}

parameters of population and species diversity in one map (Fig. 2). We applied red-grey-blue color coding in which the red channel represents the human population and the blue channel the species diversity. The cell appears red if the human population is high and species diversity is low. In the opposite case, the cell appears blue. The cells are black in the case that both population and species numbers are low. Cells appear white if the population and species diversity are high. All other combinations are represented by shades of gray. This method was adopted from Turner et al. (2004) and implemented with the $\mathrm{R} 2.71$ package Maptools.

Finally, we computed the percentage of human population in neighborhoods with below-average diversity, following Turner et al. (2004). This was done by summing the population of all raster cells with below-average diversity within a certain area and dividing it by the total population of that area. The result is an aggregated value for each municipal district and one for the whole city.

\section{Statistics}

A bivariate correlation analysis was conducted to find overlaying patterns at the municipal district level. We correlated the percentage of population living with below-average ND with all land-use and socioeconomic variables. Spearman's rho was selected as a measure of correlation because not all variables were normally distributed.

\section{RESULTS}

The highest ND is 73 , the lowest is 12 , and the mean is 47. Areas with high ND and low population density (Fig. 2, blue) are located along the floodplain and the northeast and southeast of Leipzig. The densely populated areas with low ND (Fig. 2, red) are mainly located in the west and in some eastern parts of the city. There is little cooccurrence of high population density and ND (Fig. 2, white).

In $1994,>66 \%$ of the population of Leipzig lived in neighborhoods with below-average bird diversity. The percentage of the population living with below-average ND ranges from 0 to $100 \%$ for the municipal districts, indicating great differences among them (Fig. 3).

Districts with a high percentage of population living with below-average ND are situated in the eastern 
Fig. 2. The distribution of human population and breeding bird diversity in Leipzig, Germany. ND = neighborhood bird diversity.

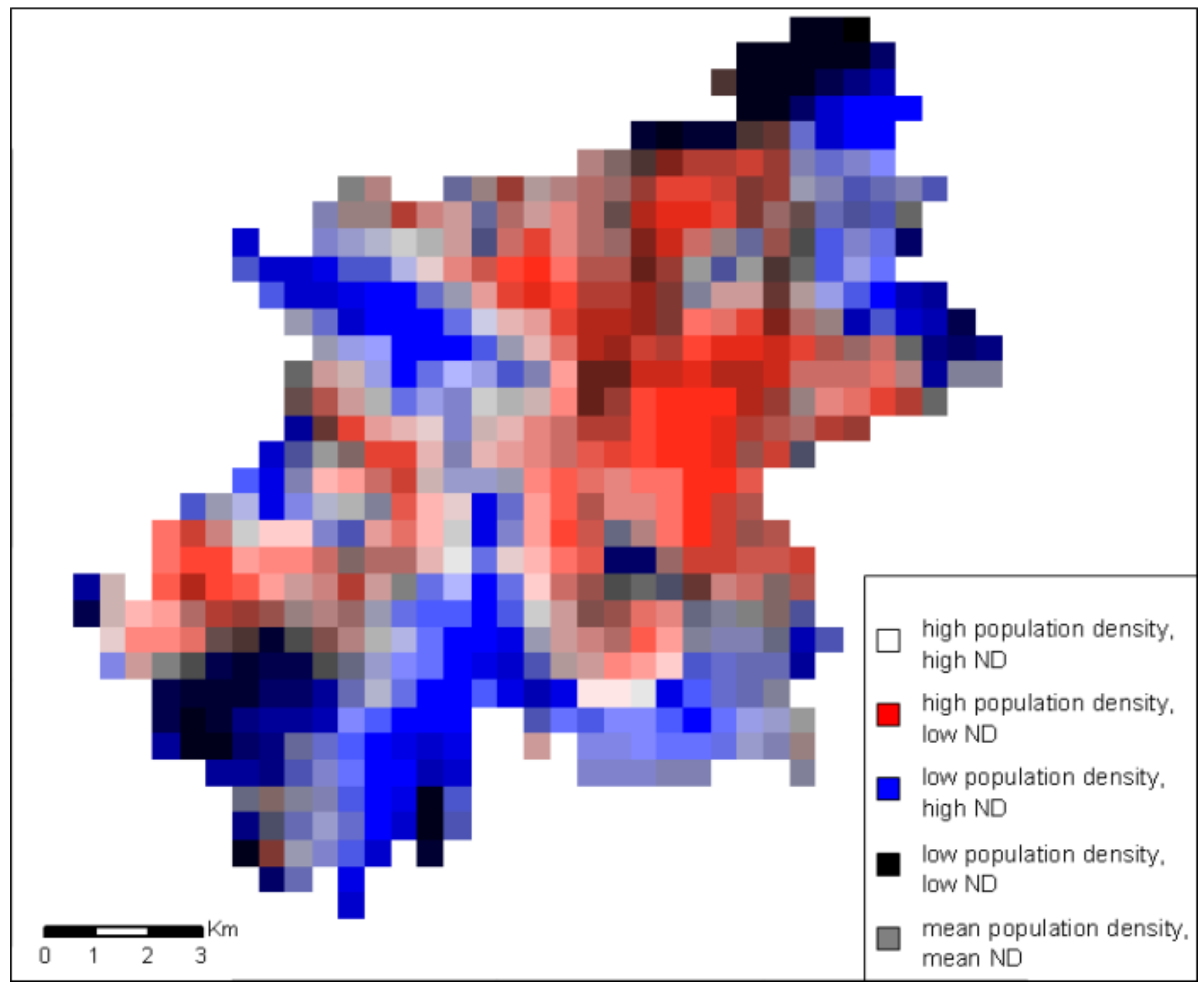

part of the city, i.e., the low-image districts of Volkmarsdorf and Neustadt-Neuschönefeld, as well as in the prefabricated housing areas of Grünau situated in the west of Leipzig. Areas with a low percentage of population living with below-average ND are located along the floodplains and at the fringe of Leipzig.

We examined the Spearman rank correlation between land use and the percentage of human population in neighborhoods with below-average ND (Table 1). There were negative correlations for land use in either natural or semi-natural habitats such as grassland $(-0.42)$, forest $(-0.65)$, river and channels $(-0.66)$ and lakes $(-0.51)$. There was a weak negative correlation for the residential landuse type of villas $(-0.25)$. A positive but weak relationship emerged for the land-use types of railway $(0.35)$ and prefabricated multistory housing estates (0.24). Other building types, parks, sports 
Fig. 3. The percentage of human population in neighborhoods with below-average bird diversity at the municipal district level.

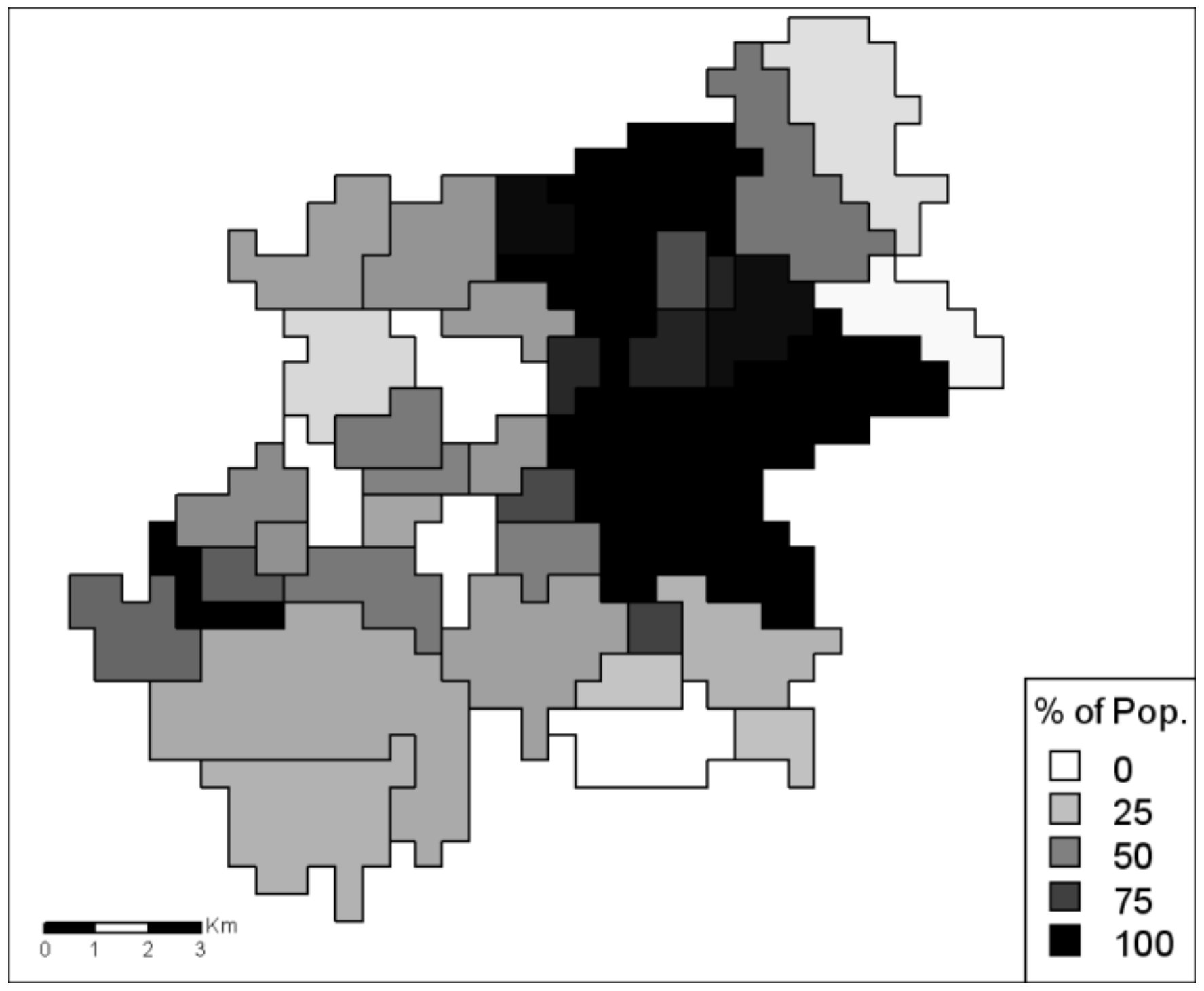

and recreation areas, allotments and cemeteries, industry and trade, major roads, and arable land did not show any significant correlations.

We also examined the Spearman rank correlation between socioeconomic data and the percentage of human population in neighborhoods with belowaverage ND (Table 2). The two indicators of landuse intensity, i.e., population density and number of companies per square-kilometer, were positively correlated with neighborhoods with below-average ND (0.44 and 0.47 , respectively). Unemployment and the share of households with income $<1000 €$ also showed a weak positive correlation $(0.25$ and 0.36 , respectively). There was a negative correlation with the share of households with income $>3000 €$ $(-0.31)$, whereas there was no significant correlation with average household size or mean age. 
In addition to the percentage of human population in neighborhoods with below-average neighborhood diversity, we also analyzed the Shannon diversity index, a common diversity index that does not require a threshold definition and is not focused on the potential to experience diversity. The results were similar to those above (Appendix 1).

\section{DISCUSSION}

The percentage of the population of Leipzig living with below-average ND is similar to that in other cities (Turner et al. 2004; Table 3). On a more detailed scale, we found that this measure differs strongly across Leipzig (Fig. 3), with high percentages of the population living with belowaverage ND in eastern districts, and low percentages along the floodplain and the fringe. We discuss how this relates to land use and socioeconomic patterns. Many relationships that have been found elsewhere were also demonstrated in Leipzig. In particular, the similarity to North American cities was surprising because there are great differences in lifestyle, urban density, and housing types. The fact that areas with high and low ND appeared both in the city and on its fringe shows that a simple rural-urban gradient does not apply to Leipzig, as it does in the case of Quebec, Canada; Rennes, France (Clergeau et al. 1998); and California, USA (Blair 1999).

\section{Land use}

Looking at underlying patterns of land use, there are clear correlations between a low percentage of people living in below-average ND and natural or semi-natural land-use types: forest, grassland, rivers and channels, and lakes. These land-use types were previously shown to be correlated with species richness (Clergeau et al. 1998, Melles et al. 2003, Blair 2004, MacGregor-Fors 2008). Railway areas, which are abundant throughout the city, do not enrich ND. Two housing types had weak correlations: residents of prefabricated multistory housing estates are more likely to experience belowaverage ND than are residents of villas. Villas are usually situated in districts such as Südvorstadt or Gohlis. They have a much higher quantity and higher quality of urban green. This is because most buildings and related house gardens, street trees, and neighborhood green structures date back more than 50 years. Additionally, they are located close to major park areas of the floodplains. In contrast, prefabricated housing estates were mainly built in the 1970s and 1980s; correspondingly, urban green in such districts is mostly very young and intensively maintained. These results are supported by Gutte and Goldberg (1986), who compared plant species richness of different parts of Leipzig. They found a much lower number of species for a prefabricated housing estate neighborhood (139 species) than for a villa quarter (212 species).

Surprisingly, there were no significant correlations between diversity and the presence of sports and recreation areas, parks, and allotments. This indicates that urban green is no guarantee for high bird diversity. This is supported by a study of bird diversity in allotments in Leipzig, which showed that allotments are structurally homogeneous throughout the city and only host common synanthropic species (Müller 2007).

\section{Socioeconomic indicators}

The results derived from socioeconomic data confirm some of the abovementioned findings from other studies and allow additional conclusions. Densely populated areas had low bird diversity, which supports findings by Tratalos et al. (2007a) for the United Kingdom and by Turner et al. (2004) for cities in North America, Europe, and Japan. In addition, Hadidian et al. (1997) found the lowest total estimated species richness in commercial areas within Washington, D.C.

Households of higher income groups tend to live within neighborhoods that exhibit higher bird diversity such as the Wilhelminian period districts in the western and southern parts of the city. By comparison, municipal districts with a high share of low-income households and a high percentage of unemployment more often show a high percentage of population living with below-average ND. These findings are in accordance with those of Melles (2005), who found that wealthier neighborhoods in Vancouver, Canada, have more native species. Hope et al. (2003) reports similar results for plant genera, and Kinzig et al. (2005) for birds and plants in Phoenix, Arizona, USA. The income effect, or "luxury effect" (Hope et al. 2003), is most likely a combination of housing choice and design. The wealthiest municipal districts in Leipzig, i.e., Gohlis and Waldstraenviertel, are located along the forests and parks of the floodplain. They have a higher 
Table 3. The percentage of human population in neighborhoods with below-average neighborhood bird diversity (ND).

\begin{tabular}{lc}
\hline \hline City & $\begin{array}{c}\text { Human population in neighborhoods with } \\
\text { below-average ND (\%) }\end{array}$ \\
\hline Western Berlin, Germany $\dagger$ & 82 \\
Eastern Berlin, Germany $\dagger$ & 65 \\
Chiba City, Japan $\dagger$ & 53 \\
Florence, Italy $\dagger$ & 77 \\
Tucson, Arizona, USA $\dagger$ & 71 \\
Washington, D.C., USA $\dagger$ & 56 \\
Leipzig, Germany & 66 \\
\hline
\end{tabular}

$\dagger$ Values from Turner et al. (2004).

quality of green, with more, older greenery and gardens compared to the rather low-income districts in the eastern part of Leipzig such as Volkmarsdorf and Neustadt-Neuschönefeld or districts with prefabricated housing estates (Grünau). MacGregorFors (2008) also showed significant positive correlations between bird species richness and older garden trees. Grove and Burch (1997), Pauleit et al. (2005), and Tratalos et al. (2007b) found more gardens and higher tree and shrub cover in areas with higher socioeconomic status. In the case of Indianapolis, Indiana, USA, Heynen (2003) provided evidence for the unequal distribution of urban trees in relation to income: the upper to middle class are favored, whereas the lower class is environmentally disadvantaged. In the case of Leipzig, it appears that a lower social status increases the chance of living in a neighborhood with below-average ND.

The potential to experience nature on a regular basis is not only determined by social status. A person's lifestyle also plays an important role. Generally speaking, not all inhabitants of a city are restricted to only using natural green space within a radius of 300 to $900 \mathrm{~m}$ around the home, a distance that governments and municipalities recommend (Handley et al. 2003, Harnik and Simms 2004, Hutter et al. 2004). However, financial well-being increases lifestyle choices and mobility in general, whereas poverty decreases both (Kinzig et al. 2005). Additionally, children are much less mobile than adults, but the availability of green space is of great importance for them while growing up (Heuser 2007) because attitudes toward nature conservation are often influenced by childhood experiences (e.g., Chawla 1998).

It might be disputed whether something as complex and subjective as the possibility of experiencing nature can be measured. We used the average ND as a threshold. Turner et al. (2004) call ND a conservative baseline, but it is obviously very case sensitive. Comparing the cities studied by Turner et al. (2004), only Florence has a higher average ND (50 species) than Leipzig (47 species). Berlin, a city located very close to Leipzig, has an average ND of approximately 23 species. This means that speciespoor neighborhoods in Leipzig could be speciesrich neighborhoods in Berlin. However, different ecosystems that are equally natural can have very different numbers of species; this explains the highest average ND for Florence, which is located in the species-rich Mediterranean. In addition, van Kamp et al. (2003:11) examined the literature on environmental quality and human well-being and conclude that the "judgment about environmental quality is always restricted to a geographical area." 
However, they also state that the definition of living area is very subjective and dependent on lifestyle and mobility. Hence, people in municipal districts with low ND might not actually feel deprived if they are immobile. In any case, a local definition of diversity is necessary, and a direct comparison to average ND from different cities is problematic.

\section{CONCLUSIONS}

Even though Leipzig is a densely built, central European city, the experience of high ND and little domesticated nature is possible. However, the neighborhood diversity indicator showed that there are patterns of inequality. To make nature experiences possible for all residents and to avoid and minimize "environmental injustice" (Low and Gleeson 1998 cited in Heynen 2003), more effort should be made in urban planning to enhance biodiversity, especially in economically poorer areas. These areas often have little and low-quality green space, and most inhabitants likely have fewer resources to spend on travel. ND is therefore a useful indicator for finding areas most in need of enhancement.

In the case of Leipzig, changes in land use caused by urban decline, recent renewal, and restructuring offer the chance to create new habitats and enhance the quality of life of many people by developing green spaces in districts where they were formerly lacking (Stadt Leipzig 2007). Approximately 5-7\% of the city is wasteland, holding great potential for the development of green space. However, to gain acceptance from local residents, it would have to be carefully designed (Mathey and Rink 2010). The effectiveness of specific measures already taken in Leipzig is yet to be shown. Great effort should also be placed on preserving existing natural green spaces from development.

These efforts are far altruistic if one considers the benefits that humans receive from green spaces, for example, climate mitigation, attractive scenery, and health benefits (Ulrich 1984). Recently, Mitchell and Popham (2008) showed that exposure to highquality green space can actually mitigate socioeconomically induced health inequalities. Additionally, people are more likely to take action to conserve biodiversity if they have direct contact with nature. The benefits and the potential to interact should be available for all residents.
Responses to this article can be read online at: http://www.ecologyandsociety.org/voll4/iss2/art31/ responses/

\section{Acknowledgments:}

We thank Judith Gläser, Stephan Pauleit, Dieter Rink, Sophie Schetke, Nina Schwarz, Ralf Seppelt, and two anonymous reviewers for valuable comments on the manuscript; Will Turnerfor advice on data visualization; and all ornithologists for their important, nonprofit work. This publication is a result of PLUREL, an Integrated Project under the European Commission's Sixth Framework Programme for research (EC FP6 Contract No. 036921). It was kindly supported by the Helmholtz Impulse and Networking Fund through the Helmholtz Interdisciplinary Graduate School for Environmental Research (HIGRADE).

\section{LITERATURE CITED}

Alberti, M., J. M. Marzluff, E. Shulenberger, G. Bradley, C. Ryan, and C. Zumbrunnen. 2003. Integrating humans into ecology: opportunities and challenges for studying urban ecosystems. Bioscience 53(12):1169-1179.

Baines, C. 2000. How to make a wildlife garden. Second edition. Francis Lincoln, London, UK.

Blair, R. B. 1999. Birds and butterflies along an urban gradient: surrogate taxa for assessing biodiversity? Ecological Applications 9(1):164-170.

Blair, R. 2004. The effects of urban sprawl on birds at multiple levels of biological organization. Ecology and Society 9(5): 2. [online] URL: http://w ww.ecologyandsociety.org/vol9/iss5/art2/.

Buckland, S. T., A. E. Magurran, R. E. Green, and R. M. Fewster. 2005. Monitoring change in biodiversity through composite indices. Philosophical Transactions of the Royal Society B: Biological Sciences 360(1454):243-254.

Center for International Earth Science Information Network. 2004. Global rural-urban mapping project. Columbia University, New York, USA. [online] URL: http://sedac.ciesin.columbia.edu/ gpw. 
Chawla, L. 1998. Significant life experiences revisited: a review of research on sources of environmental sensitivity. Environmental Education Research 4(4):369-382.

Chiesura, A. 2004. The role of urban parks for the sustainable city. Landscape and Urban Planning 68 (1):129-138.

Clergeau, P., L. Jokimäki, and J.-P. L. Savard. 2001. Are urban bird communities influenced by the bird diversity of adjacent landscapes? Journal of Applied Ecology 38(5):1122-1134.

Clergeau, P., J. Jokimäki, and R. Snep. 2006. Using hierarchical levels for urban ecology. Trends in Ecology and Evolution 21(12):660-661.

Clergeau, P., J.-P. L. Savard, G. Mennechez, and G. Falardeau. 1998. Bird abundance and diversity along an urban-rural gradient: a comparative study between two cities on different continents. Condor 100(3):413-425.

Crane, P., and A. Kinzig. 2005. Nature in the metropolis. Science 308(5726): 1225.

DeGraaf, R. M., A. D. Geis, and P. A. Healy. 1991. Bird population and habitat surveys in urban areas. Landscape and Urban Planning 21(3):181-188.

Dow, K. 2000. Social dimensions of gradients in urban ecosystems. Urban Ecosystems 4(4):255-275.

Dunn, R. R., M. C. Gavin, M. C. Sanchez, and J. N. Solomon. 2006. The pigeon paradox: dependence of global conservation on urban nature. Conservation Biology 20(6):1814-1816.

Fuller, R. A., K. N. Irvine, P. Devine-Wright, P. H. Warren, and K. J. Gaston. 2007. Psychological benefits of greenspace increase with biodiversity. Biology Letters 3(4):390-394.

Grimm, N. B., S. H. Faeth, N. E. Golubiewski, C. L. Redman, J. Wu, X. Bai, and J. M. Briggs 2008. Global change and the ecology of cities. Science 319(5864):756-760.

Grove, J. M., and W. R. Burch. 1997. A social ecology approach and applications of urban ecosystem and landscape analyses: a case study of
Baltimore, Maryland. Urban Ecosystems 1 (4):259-275.

Gutte, P., and A. Goldberg. 1986. Floristischer Vergleich ausgewählter ökologischer Raumeinheiten Leipzigs. Wissenschaftliche Zeitschrift der KarlMarx-Universität Leipzig, Mathematisch-

Naturwissenschaftliche Reihe 35:661-672.

Haase, A., A. Steinführer, and S. Kabisch. 2004. Results of the questionnaire survey in Leipzig. Workpackage 2 of Re Urban Mobil. UFZ Leipzig, Leipzig, Germany. Available online at: http://www. re-urban.com/downloads/SurveyReportLeipzig.pdf

Haase, D. 2003. Holocene floodplains and their distribution in urban areas-functionality indicators for their retention potentials. Landscape and Urban Planning 66(1):5-18.

Haase, D., and H. Nuissl. 2007. Does urban sprawl drive changes in the water balance and policy?: The case of Leipzig (Germany) 1870-2003. Landscape and Urban Planning 80(1):1-13.

Hadidian, J., J. Sauer, C. Swarth, D. Handly, S. Droege, C. Williams, J. Huff, and G. Didden. 1997. A citywide breeding bird survey for Washington, D.C. Urban Ecosystems 1(2):87-102.

Handley, J., S. Pauleit, P. Slinn, A. Barber, M. Baker, C. Jones, and S. Lindley. 2003. Accessible natural green space standards in towns and cities. a review and toolkit for their implementation. English Nature Research Reports Number 526. English Nature, Peterborough, UK. Available online at: http://www.Inr.naturalengland.org.uk/Special/ $\underline{\text { lnr/pdf/GreenSpaceReport.pdf. }}$

Heuser, J. 2007. Wildniss für Kinder in der Stadt [Wilderness for children in the city]. Conturec 2:153-158. [In German, with English summary].

Heynen, N. C. 2003. The scalar production of injustice within the urban forest. Antipode $\mathbf{3 5}$ (5):980-998.

Hope, D., C. Gries, W. Zhu, W. F. Fagan, C. L. Redman, N. B. Grimm, A. L. Nelson, C. Martin, and A. Kinzig. 2003. Socioeconomics drive urban plant diversity. Proceedings of the National Academy of Science 100(15):8788-8792. 
Harnik, P., and J. Simms. 2004. Parks: How far is too far? Planning 70(11):8-11. Available online at: http://www.tpl.org/content documents/ cityparks Planning mag article12 2004.pdf.

Hutter, G., C. Westphal, S. Siedentop, G. Janssen, and B. Müller. 2004. Handlungsansätze zur Berücksichtigung der Umwelt-, Aufenthaltsund Lebensqualität im Rahmen der Innenentwicklung von Städten und Gemeinden - Fallstudien. Umweltbundesamt Texte 41. Umweltbundesamt, Berlin, Germany.

Kabisch, S., M. Bernt, and A. Fritzsche. 2005. Grünau 2004 - Einwohnerbefragung im Rahmen der Intervallstudie "Wohnen und Leben in LeipzigGrünau”: Ergebnisbericht. UFZ-Umweltforschungszentrum Leipzig-Halle, Leipzig, Germany. Available online at: http://www.ufz.de/data/Interva llstudie Leipzig-Gruenau2649.pdf.

Kareiva, P., S. Watts, R. McDonald, and T. Boucher. 2007. Domesticated nature: shaping landscapes and ecosystems for human welfare. Science 316(5833):1866-1869.

Kinzig, A. P., P. Warren, C. Martin, D. Hope, and M. Katti. 2005. The effects of human socioeconomic status and cultural characteristics on urban patterns of biodiversity. Ecology and Society 10(1): 23. [online] URL: http://www.ecologyandso ciety.org/vol10/iss1/art23/.

Legendre, P., and L. Legendre. 1998. Numerical ecology. Elsevier, Amsterdam, The Netherlands.

MacGregor-Fors, I. 2008. Relation between habitat attributes and bird richness in a western Mexico suburb. Landscape and Urban Planning 84 (1):92-98.

Marzluff, J. M. 2001. Worldwide urbanization and its effects on birds. Pages 19-47 in J. M. Marzluff, R. Bowman, and R. Donnelly, editors. Avian ecology and conservation in an urbanizing world. Kluwer, Boston, Massachusetts, USA.

Mathey, J., and D. Rink. 2010. Urban wastelands a chance for biodiversity in cities? Ecological aspects, social perceptions and acceptance of wilderness by residents. In N. Müller, P. Werner, and J. G. Kelcey, editors. Urban Biodiversity and
Design. Wiley-Blackwell, Hoboken, New Jersey, USA.

Melles, S. J. 2005. Urban bird diversity as an indicator of social diversity and economic inequality in Vancouver, British Columbia. Urban Habitats 3(1):25-48.

Melles, S., S. Glenn, and K. Martin. 2003. Urban bird diversity and landscape complexity: speciesenvironment associations along a multiscale habitat gradient. Conservation Ecology 7(1): 5. [online] URL: http://www.consecol.org/vol7/iss1/art5/.

Millard, A. 2008. Semi-natural vegetation and its relationship to designated urban green space at the landscape scale in Leeds, UK. Landscape Ecology 23(10):1231-1241.

Miller, J. R. 2005. Biodiversity conservation and the extinction of experience. Trends in Ecology and Evolution 20(8):430-434.

Mitchell, R., and F. Popham. 2008. Effect of exposure to natural environment on health inequalities: an observational population study. Lancet 372(9650):1655-1660.

Müller, G. K. 1995. Die Leipziger Auen: Bestandsaufnahme und Vorschläge für die Gebietsentwicklung. Materialien zu Naturschutz und Landschaftspflege, Freistaat Sachsen, Germany.

Müller, N. 2007. Bestandsentwicklung von Brutvögeln ausgewählter Kleingartenanlagen Leipzigs. Diploma thesis. Hochschule Anhalt (FH), Bernburg, Germany.

Pauleit, S., R. Ennos, and Y. Golding. 2005. Modeling the environmental impacts of urban land use and land cover change - a study in Merseyside, UK. Landscape and Urban Planning 71 (2-4):295-310.

Sandström, U. G., P. Angelstam, and G. Mikusinski. 2006. Ecological diversity of birds in relation to the structure of urban green space. Landscape and Urban Planning 77(1-2):39-53.

Savard, J.-P. L., P. Clergeau, and G. Mennechez. 2000. Biodiversity concepts and urban ecosystems. Landscape and Urban Planning 48(3-4):131-142. 
Stadt Leipzig. 1995. Ortsteilkatalog 1995. Amt für Statistik und Wahlen, Stadt Leipzig, Germany.

Stadt Leipzig. 1997. Ortsteilkatalog 1997. Amt für Statistik und Wahlen, Stadt Leipzig, Germany.

Stadt Leipzig. 2004. Ortsteilkatalog 2004. Amt für Statistik und Wahlen, Stadt Leipzig, Germany.

Stadt Leipzig. 2007. Monitoringbericht 2006. Amt für Statistik und Wahlen, Stadt Leipzig, Germany.

Stefens, R., R. Kretzschmar, and S. Rau. 1998. Atlas der Brutvögel Sachsens. Sächsisches Landesamt für Umwelt und Geologie, Dresden, Germany.

STUFA. 1995. Brutvogelatlas der Stadt und des Landkreises Leipzig. Materialien zu Naturschutz und Landschaftspflege, Freistaat Sachsen, Germany.

Tratalos, J., R. A. Fuller, K. L. Evans, R. G. Davies, S. E. Newson, J. J. D. Greenwood, and K. J. Gaston. 2007a. Bird densities are associated with household densities. Global Change Biology 13(8):1685-1695.

Tratalos, J., R. A. Fuller, P. H. Warren, R. G. Davies, and K. J. Gaston. 2007b. Urban form, biodiversity potential and ecosystem services. Landscape and Urban Planning 83(4):308-317.

Turner, W. R., T. Nakamura, and M. Dinetti. 2004. Global urbanization and the separation of humans from nature. BioScience 54(6):585-590.

Ulrich, R. S. 1984. View through a window may influence recovery from surgery. Science $\mathbf{2 2 4}$ (4647):420-421.

United Nations. 2008. World population prospects: the 2007 revision population database. United Nations, New York, NY, USA. [online] URL: http ://esa.un.org/unup.

van Kamp, I., K. Leidelmeijer, G. Marsman, and A. de Hollander. 2003. Urban environmental quality and human well-being: towards a conceptual framework and demarcation of concepts; a literature study. Landscape and Urban Planning $\mathbf{6 5}$ (1-2):5-18.
Völkl, W., T. Blick, P. M. Kornacker, and H. Martens. 2004. Quantitativer Überblick über die rezente Fauna von Deutschland. Natur und Landschaft 79(7):293-295. 
Appendix 1. A correlation analysis between the Shannon Diversity Index and land use as well as socioeconomic parameters for Leipzig, Germany.

Please click here to download file 'appendix1.pdf'. 